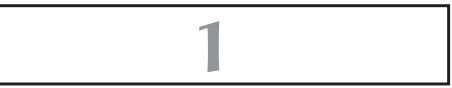

\title{
OS GOVERNANTES DEVEM PRESTAR CONTAS
}

\author{
A sociedade tem o direito de exigir de todo agente \\ público que preste contas de sua administração. \\ (Declaração dos direitos do homem \\ e do cidadão, 1789) ${ }^{29}$
}

Democratismo, republicanismo e liberalismo. As democracias representativas contemporâneas resultam da simbiose dessas três correntes ou tradições históricas, como acreditava Guillermo O’Donnell ${ }^{30}$.

Por democracias representativas contemporâneas, neste trabalho, tomam-se aquelas ordens políticas batizadas de poliarquias. Para que façam jus ao termo cunhado por Robert Alan Dahl ${ }^{31}$, devem estar simultaneamente presentes, no regime, sete instituições, a saber: (i) governantes eleitos; (ii) eleições frequentes, livres e justas; (iii) sufrágio universal; (iv) direito de praticamente todos os adultos concorrerem aos cargos eletivos; (v) liberdade de expressão; (vi) existência de fontes de informação alternativas ao governo; e (vii) liberdade de associação.

Antes de Guillermo O’Donnell, o próprio Robert Alan Dahl afirmou que as poliarquias podem ser entendidas, também, como “[...] resultado histórico dos esforços para democratizar e liberalizar as instituições políticas dos Estados-nação"32. Além disso, como ensina, as referidas sete instituições da poliarquia são absolutamente ne-

29 FRANCE. Assemblée Nationale Constituante (1789). Déclaration des Droits de l'Homme et du Citoyen de 1789. Disponível em: https://www.legifrance.gouv.fr/Droit-francais/Constitution/Declaration-des-Droits-de-1-Homme-et-du-Citoyen-de-1789. Acesso em: 17 out. 2019.

30 O’DONNELL, Guillermo. Accountability horizontal e novas poliarquias. Lua Nova, São Paulo, n. 44, p. 27-54, 1998. p. 30.

31 DAHL, Robert Alan. Democracy and its critics. New Haven: Yale University Press, 1989. p. $220-221$.

32 DAHL, Robert Alan. Democracy and its critics. New Haven: Yale University Press, 1989. p. 218 (tradução nossa). 


\section{•- Contas dos governantes}

cessárias - embora talvez não sejam suficientes - à democracia em larga escala, como no Estado nacional contemporâneo ${ }^{33}$.

Ora, se as tradiçôes democrática, republicana e liberal foram essenciais na formação das democracias atuais, sua influência é global, especialmente considerando que, como celebrou Francis Fukuyama ${ }^{34}$, após a derrocada do bloco socialista, a democracia representativa triunfou sobre suas alternativas, a ponto de estas terem sido consideradas inviáveis, como destacou Frank Ankersmit ${ }^{35}$.

Segundo Francis Fukuyama, entre avanços e retrocessos de curto prazo, a escalada no número de Estados que podem ser considerados democráticos - três em 1807; treze em 1939; trinta e cinco em 1970; mais de sessenta em 1989; e mais de cento e dez em $2014^{36}$ - resulta da superioridade normativa dos princípios que a sustentam que, para ele, “[...] estão no final de um longo processo de evolução ideológica, não existindo um melhor conjunto de princípios alternativos que poderiam lhes substituir"37.

Esteja ou não no final da trilha evolutiva ${ }^{38}$, é fato que, tendo adquirido legitimidade universal, como defende Luís Felipe Miguel, a democracia representativa, nos “[...] países do Ocidente, é o único regime político capaz de garantir a aceitação dos governados" 39 . Semelhantemente, de acordo com a espanhola María Ángeles Abellán López, "A democracia liberal aparece hoje como a única forma legítima de organização do poder, nenhuma alternativa real à vista e considerada um fenômeno quase universal" 40 .

No país, a CRFB/1988 evidencia essa inspiração ainda no caput de seu artigo $1^{\circ}$, que enuncia: "A República Federativa do Brasil, formada pela união indissolúvel dos Estados e Municípios e do Distrito Federal, constitui-se em Estado Democrático de

3 DAHL, Robert Alan. Democracy and its critics. New Haven: Yale University Press, 1989. p. 221-222.

34 FUKUYAMA, Francis. The end of history and the last man. New York: The Free Press, 1992; FUKUYAMA, Francis. Liberal democracy as a global phenomenon. PS: Political Science \& Politics, Cambridge, p. 659-664, Dec. 1991. p. 664.

35 ANKERSMIT, Frank. Democracia representativa. Antíteses, Londrina, v. 6, n. 12, p. 456-467, jul./ dez. 2013. p. 457.

36 Cf. FUKUYAMA, Francis. Reflections on the end of history, five years later. History and Theory, Washington, v. 34, n. 2, p. 27-43, May 1995. p. 31; e FUKUYAMA, Francis. Why is democracy performing so poorly? Journal of Democracy, Washington, v. 26, n. 1, p. 11-20, 2015. p. 11.

37 FUKUYAMA, Francis. Reflections on the end of history, five years later. History and Theory, Washington, v. 34, n. 2, p. 27-43, May 1995. p. 30 (tradução nossa).

38 Recentes obras, de abalizados autores, alertam para riscos que se avizinham sobre as democracias, com potencial para levar à sua crise, declínio ou colapso, cf. CASTELLS, Manuel. Ruptura: a crise da democracia liberal. Rio de Janeiro: Zahar, 2018; LEVITSKY, Steven; ZIBLATT, Daniel. How democracies die. New York: Crown Publishing, 2018; e RUNCIMAN, David. How democracy ends. London: Profile Books, 2018.

39 MIGUEL, Luís Felipe. Impasses da accountability: dilemas e alternativas da representação política. Revista de Sociologia e Política, Curitiba, n. 25, p. 25-38, nov. 2005. p. 25-26.

40 ABELLÁN LÓPEZ, María Ángeles. El influjo de la tradición republicana en la democracia representativa contemporánea. Revista de La Facultad de Ciencias Sociales y Jurídicas, Elche, v. I, n. 10, p. 127-141, jul. 2014. p. 130 (tradução nossa). 
Direito [... $]^{\prime ׳ 41}$. Observe-se que, além de nomear o Estado brasileiro como uma república - "República Federativa do Brasil”, expressão do republicanismo -, o legislador constituinte o qualificou como democrático - a partir do democratismo - e de direito - portanto, não absoluto, limitado, ou seja, liberal, na medida em que preserva certas liberdades públicas.

Ao interpretar a Constituição, portanto, deve-se ter em mente que, como observa Uadi Lammêgo Bulos ${ }^{42}$, os princípios consagrados no transcrito artigo $1^{\circ}$, e com eles a influência das tradições clássicas, irradiam-se por todos os campos da esfera constitucional brasileira.

Logo, para bem interpretar e aplicar os mecanismos institucionais desenhados pela CRFB/1988, é necessário um esforço para compreender minimamente as tradições que inspiraram sua construção, quais sejam, o democratismo, o republicanismo e o liberalismo.

\subsection{DEMOCRATISMO, REPUBLICANISMO E LIBERALISMO}

Aristóteles ${ }^{43}$ considerava a democracia, entre as seis espécies de governo que classificou, como um desvio da politeia ${ }^{44}$. No entanto, considerando uma realidade na qual os governantes frequentemente agiam em seu próprio interesse, em detrimento do interesse da população como um todo, ele a reconheceu como a mais tolerável entre os prováveis desvios do governo apropriado. Como explica Frank Cunningham ${ }^{45}$, ao menos na democracia mais pessoas se beneficiariam da regra de auto interesse - em detrimento do interesse do todo -, as experiências coletivas de muitas pessoas podiam ser vantajosas e o descontentamento majoritário seria atenuado.

Como ensinava Robert Alan $\mathrm{Dahl}^{46}$, a ideia fundamental do democratismo, desde a antiguidade, é que os membros da sociedade se consideram como iguais, coletivamente soberanos e detentores das capacidades, dos recursos e das instituiçóes necessárias para governar a si próprios. Pelo pressuposto da igualdade, por ele explicitado, numa democracia, todos os membros são considerados como suficientemente qualifi-

41 BRASIL. Constituição (1988). Constituição da República Federativa do Brasil. Disponível em: http:// www.planalto.gov.br/ccivil_03/Constituicao/Constituicao.htm. Acesso em: 2 dez. 2019.

42 BULOS, Uadi Lammêgo. Curso de direito constitucional. 9. ed. São Paulo: Saraiva, 2015. p. 507.

43 ARISTÓTELES. Politics. Translated by Benjamin Jowett. Kitchener: Batoche Books, 1999. Disponível em: http://www.dominiopublico.gov.br/download/texto/mc000010.pdf. Acesso em: 18 maio 2020. p. 82 .

44 Algumas traduções apresentam a democracia como uma das três formas virtuosas de governo, na qual a maioria dos cidadãos deveria governar em prol do interesse geral, não como um de seus desvios, cf. ARISTÓTELES. Politics: a treatise on government. Translated by William Ellis. London: J. M. Dent \& Sons, 1912. Project Gutemberg: 2009. p. 223-225 (e-Book).

45 CUNNINGHAM, Frank. Theories of democracy: a critical introduction. New York: Routledge, 2002. p. 7 (tradução nossa).

46 DAHL, Robert Alan. Democracy and its critics. New Haven: Yale University Press, 1989. p. 1; 98. 


\section{•. Contas dos governantes}

cados para participar na tomada de decisões coletivas vinculativas sobre a associação, sempre que tais decisóes possam afetar significativamente seu bem-estar ou seus interesses. De igual modo, segundo ele, considerando a igualdade como premissa, nenhum deles seria tão mais qualificado do que os outros de forma que lhe devessem ser confiadas definitivamente as decisôes coletivas e vinculativas.

Pelo exposto, observe-se que a adoção da igualdade como pressuposto implica a necessidade, no momento em que as decisóes devem ser tomadas, tanto de igual consideração de interesses como da possibilidade de participação dos membros individualmente considerados.

É que o processo democrático é um “[...] requisito para a tomada de decisões vinculativas”, ${ }^{\$ 7}$. Nesse sentido, segundo Jon Elster ${ }^{48}$, todos concordam que a noção de democracia inclui a tomada de decisão coletiva mediante a possibilidade de participação - direta ou indireta - de todos os que poderão ser por ela afetados. Essa é, como ensina Cícero Araújo ${ }^{49}$, uma expressão do ideal de plebeísmo, umbilicalmente ligado à tradição democrática.

Mas não é só. De acordo com Robert Alan Dahl, apenas poderão tomar parte num processo decisório democrático as pessoas sujeitas às decisões, portanto, os membros da associação. Assim, como afirma, “[...] leis não podem ser impostas aos outros por pessoas que não sejam, elas próprias, obrigadas a obedecer a tais leis" ${ }^{20}$.

A tradição republicana, por sua vez, como ensina Robert Alan Dahlin , tem sua fonte mais em Roma e nas cidades-estado italianas medievais e renascentistas do que na Grécia antiga. Está profundamente ligada ao ideal cívico, que seria, segundo Cícero Araújo ${ }^{52}$, um ideal de excelência na cidadania, cuja aplicação, na medida em que reflete uma preocupação com o caráter e com a virtude, atinge e restringe o tipo de pessoas que estariam aptas a participar da comunidade política como cidadãos.

Nesse sentido, Fernando Facury $S_{c a f f}{ }^{33}$ relaciona o conceito de república à ideia romana de coisa pública e destaca que o governo republicano, ao perseguir os interesses do bem comum, deve proteger e conservar a coisa pública, sempre com obediência à lei.

DAHL, Robert Alan. Democracy and its critics. New Haven: Yale University Press, 1989. p. 105 (tradução nossa).

48 ELSTER, Jon (Org.). Deliberative democracy. Cambridge: Cambridge University Press, 1998. p. 8.

49 ARAÚJO, Cícero. República e democracia. Lua Nova, São Paulo, n. 51, p. 5-30, 2000 . p. 6.

50 DAHL, Robert Alan. Democracy and its critics. New Haven: Yale University Press, 1989. p. 107-108 (tradução nossa).

51 DAHL, Robert Alan. Democracy and its critics. New Haven: Yale University Press, 1989. p. 13.

52 ARAÚJO, Cícero. República e democracia. Lua Nova, São Paulo, n. 51, p. 5-30, 2000. p. 5-6.

53 SCAFF, Fernando Facury. Orçamento republicano e liberdade igual: ensaio sobre direito financeiro, república e direitos fundamentais no Brasil. Belo Horizonte: Fórum, 2018. p. 113. 
A terceira tradição, liberal, como explicou Guillermo O'Donnell54, deriva da desconfiança que os cidadãos nutrem em relação aos detentores do poder, especialmente se esse poder inclui a possibilidade de coerção contra os membros da sociedade. A partir do liberalismo, o cidadão conquistou a titularidade de direitos que, quando respeitados, limitam o poder dos governantes. Dessa maneira, Andrew Arato ${ }^{55}$ aponta o constitucionalismo e seus instrumentos mais importantes - a constituição escrita, por exemplo - como fundamentais para garantir que as regras do jogo não estejam à disposição dos governantes, na medida em que reservam certos poderes aos cidadãos.

A construção do constitucionalismo, como se vê hoje, naturalmente resulta de esforços contínuos influenciados pela tradição liberal, como explica o colombiano Leonel Esteban Martínez Castro, no seguinte trecho:

Assim, a tradição liberal apresenta as suas instituições mais influentes, desde as grandes declarações de princípios do século XVIII, de sua inclusão nas cartas políticas formais no século XIX, passando pela proclamação dos direitos humanos e universais ao longo do século XX, até atingir a recente criação de constituiçôes rígidas, com os direitos fundamentais, tais como estruturas neutras e objetivas capazes de representar todos os indivíduos ${ }^{56}$.

Encerrados no constitucionalismo, além dos direitos e garantias fundamentais, os mecanismos combinados da separação dos poderes - defendida por Charles de Secondat, o Barão de Montesquieu ${ }^{57}$ - e dos checks and balances - desenvolvidos por James Madison ${ }^{58}$-, na medida em que possibilitam o controle mútuo entre os detentores de poder, inibem o abuso de poder do Estado em prejuízo dos governados - ainda que não seja essa sua finalidade precípua, como se apresenta na subseção 1.5 .2 (p. 62) deste trabalho.

Leonel Esteban Martínez Castro ${ }^{59}$ destaca que, segundo a tradição liberal, direitos como a liberdade pessoal e a propriedade privada decorreriam diretamente do di-

54 O'DONNELL, Guillermo. Horizontal accountability: the legal institutionalization of mistrust. In: MAINWARING, Scott; WELNA, Christoper. Democratic accountability in Latin America. New York: Oxford University Press, 2003. p. 41.

55 ARATO, Andrew. Representação, soberania popular e accountability. Lua Nova, São Paulo, n. 55/56, p. $85-103,2002$. p. $87-88$

56 MARTÍNEZ CASTRO, Leonel Esteban. Constitucionalismo liberal contemporáneo vs democracia. Oxímora Revista Internacional de Ética y Política, Barcelona, n. 1, p. 40-52, oct. 2012. p. 46 (tradução nossa).

57 MONTESQUIEU, Charles de Secondat, Baron de. The spirit of laws. Translated by Thomas Nugent. Kitchener: Batoche Books, 2001. Disponível em: http://www.dominiopublico.gov.br/download/texto/ mc000219.pdf. Acesso em: 7 fev. 2017.

58 MADISON, James. The Federalist, No. LI: The structure of government must furnish the proper checks and balances between the different departments. In: The Constitution of the United States of America: and selected writings of the founding fathers. New York: Barnes \& Noble, 2012. p. 484-488.

59 MARTÍNEZ CASTRO, Leonel Esteban. Constitucionalismo liberal contemporáneo vs democracia. Oxímora Revista Internacional de Ética y Política, Barcelona, n. 1, p. 40-52, oct. 2012. p. 45-50. 


\section{-. Contas dos governantes}

reito natural, devendo ser respeitados em todas as sociedades, independentemente de sua organização. Por isso, segundo ele, "Estes valores universais dependem de palavras sagradas como o Estado de direito, constituição e liberdade"60.

A liberdade pessoal, defendida pela tradição liberal, é expressão do ideal normativo do pluralismo, descrito por Cícero Araújo como "[...] um ideal de tolerância para com os diferentes estilos de vida e crenças religiosas e filosóficas dos cidadãos"

Ter em mente as principais características de cada uma dessas três tradições clássicas, apresentadas nesta seção, é essencial para bem compreender sua interação na formação das democracias representativas contemporâneas. Na próxima seção, voltar-se-á o olhar para o modo como as tradiçóes democrática, republicana e liberal relacionam-se na formação das democracias atuais.

\subsection{O ARRANJO ENTRE TRÊS TRADIÇÕES EM TENSÃO}

Na jornada para compreender a influência do democratismo, do republicanismo e do liberalismo, é fundamental destacar que essas três tradições, ainda que se mostrem complementares nas contemporâneas democracias representativas, estão em permanente tensão entre si, como destaca Charles D. Kenney ${ }^{62}$.

Corroboram com tal entendimento as lições de Cícero Araújo ${ }^{63}$, que apresenta a relação de complementariedade e tensão entre os três ideais normativos da cidadania democrática, quais sejam, (i) civismo; (ii) plebeísmo; e (iii) pluralismo, intimamente ligados, como apresentado anteriormente, ao republicanismo, ao democratismo e ao liberalismo, respectivamente.

Tome-se, por exemplo, a relação entre as esferas pública e privada. Como apresentou Guillermo O’Donnell ${ }^{64}$, enquanto a democracia, em sua origem ateniense, era monista, sem relevante separação entre as esferas pública e privada, as tradições republicana e liberal estabelecem nítida divisão entre elas.

Porém, enquanto o republicanismo valoriza a esfera pública, como aquela na qual o homem alcança todo o seu potencial - "A virtude é dedicar-se altruisticamente ao bem público, sem permitir que interesses particulares ou faccionais interfiram nessa

\footnotetext{
MARTÍNEZ CASTRO, Leonel Esteban. Constitucionalismo liberal contemporáneo vs democracia. Oxímora Revista Internacional de Ética y Política, Barcelona, n. 1, p. 40-52, oct. 2012. p. 46 (tradução nossa).

${ }_{61}$ ARAÚJO, Cícero. República e democracia. Lua Nova, São Paulo, n. 51, p. 5-30, 2000. p. 5.

62 KENNEY, Charles D. Horizontal accountability: concepts and conflicts. In: MAINWARING, Scott; WELNA, Christoper. Democratic accountability in Latin America. New York: Oxford University Press, 2003. p. 68.

63 ARAÚJO, Cícero. República e democracia. Lua Nova, São Paulo, n. 51, p. 5-30, 2000. p. 5.

${ }^{64}$ O'DONNELL, Guillermo. Horizontal accountability: the legal institutionalization of mistrust. In: MAINWARING, Scott; WELNA, Christoper. Democratic accountability in Latin America. New York: Oxford University Press, 2003. p. 37-39.
} 
busca" $^{\prime \prime 5}$-, o liberalismo realça o âmbito privado, esfera na qual suas potencialidades podem ser plenamente alcançadas.

O conceito de igualdade política é outro ponto de tensão entre tradições que influenciaram a formação das democracias representativas contemporâneas. Como ensina Cícero Araújo ${ }^{66}$, a noção democrática de igualdade política extensiva a todos, como direito decorrente do fato de estar sujeito às mesmas normas que os demais, e a heterogeneidade do corpo de cidadãos dela decorrente, choca-se com a noção republicana de igualdade política, que supóe que os membros de uma comunidade política compartilhem vínculos especiais e as qualidades morais - virtude - necessárias para preservar esses vínculos.

Também há tensão em relação à visão de autoridade política em cada tradição. Segundo Guillermo O'Donnell ${ }^{67}$, enquanto, por diferentes motivos, o democratismo e o republicanismo não impõem limites ao governo, o liberalismo argumenta que existem direitos que não podem ser licitamente violados, nem pelo Estado ou seus agentes, nem por particulares.

Até a desnecessidade de imposição de limites ao governo, apesar de compartilhada pelo democratismo e pelo republicanismo clássicos, encontra em cada uma dessas tradições diferentes justificativas. No ideal democrático, não haveria razão para se aceitar restrições às decisões tomadas coletivamente. Por outro lado, na república pura, não se deveria impedir, com a fixação de limites, aqueles que são mais virtuosos de governar em nome do bem comum.

Elena García Guitián ${ }^{68}$, por sua vez, apresenta o contraste entre os conceitos de liberdade das tradiçōes liberal e republicana. Segundo ela, ao tempo em que o liberalismo defende uma liberdade dita negativa, onde a autonomia do sujeito somente pode ser exercida numa área livre de interferência do Estado, o republicanismo justifica que o Estado deve intervir ativamente para garantir a liberdade, sempre que a autonomia do sujeito somente possa ser verdadeiramente exercida se eliminadas ou atenuadas determinadas desigualdades existentes.

Como se vê, apesar de conviverem de forma relativamente harmoniosa no arranjo formado nas democracias atuais, caso fosse considerada apenas a visão ideal de quaisquer entre as tradições democrática, republicana e liberal, a solução finalmente adotada pelo sistema político, em diversos aspectos, teria sido substancialmente diferente.

65 O'DONNELL, Guillermo. Horizontal accountability: the legal institutionalization of mistrust. In: MAINWARING, Scott; WELNA, Christoper. Democratic accountability in Latin America. New York: Oxford University Press, 2003. p. 38 (tradução nossa).

${ }_{66}$ ARAÚJO, Cícero. República e democracia. Lua Nova, São Paulo, n. 51, p. 5-30, 2000. p. 24.

${ }_{67}$ O’DONNELL, Guillermo. Accountability horizontal e novas poliarquias. Lua Nova, São Paulo, n. 44, p. 27-54, 1998. p. 33.

68 GARCÍA GUITIÁN, Elena. Liberalismo y republicanismo: el uso político de los conceptos de libertad. Revista Internacional de Pensamiento Político, Sevilla, v. 1, v. 4, p. 29-45, 2009. p. 34-41. 


\section{•. Contas dos governantes}

Dessa forma, Guillermo O’Donnell ${ }^{69}$, ao rejeitar a colocação de uma dessas tradiçôes como alicerce mais fundamental das poliarquias, em detrimento das demais, ensinou que (i) a exaltação do liberalismo resultaria em "[...] 'liberismo', a defesa do laissez-faire econômico e do governo oligárquico por aqueles que estão entrincheirados em seus privilégios"; (ii) a adoção pura do princípio democrático majoritário carregaria consigo uma série de riscos inaceitáveis; e (iii) a dominância do republicanismo tenderia a tornar "[...] o governo paternalista de uma elite que se autopresume moralmente superior".

Semelhantemente, como defende Cícero Araújo, ainda que a ênfase de um entre os ideais do civismo, do plebeísmo e do pluralismo - e, portanto, da tradição política a ele relacionada - seja compatível com a democracia, a supressão de qualquer deles num regime impede que este seja considerado uma democracia representativa, nos moldes atuais. Segundo ele,

[...] a justificação moral do Estado democrático funda-se na coexistência desses três ideais: a total ausência de um deles implica solapar as bases normativas da democracia. A tensão significa que as exigências implícitas em cada um deles, levadas às últimas conseqüências, os colocam em irremediável conflito com os demais. Estados democráticos resultam de determinados arranjos ou composições entre os princípios que os justificam, e uma das causas da variedade histórica das democracias provém da maior ou menor ênfase de um dos componentes em relação aos outros dois: há democracias que são mais "cívicas" e menos "pluralistas", outras que são mais "plebeístas" e menos "cívicas" e assim por diante ${ }^{70}$.

É justamente a multiplicidade de formas possíveis em que pode se dar o arranjo entre as tradições históricas analisadas que dá à democracia representativa a flexibilidade necessária para se tornar o sistema político dominante. É o que, atualmente, permite classificar como democracias regimes tão diferentes entre si, como os vigentes no Brasil, na África do Sul, na Alemanha, na Austrália, em Botswana, em Cabo Verde, no Canadá, na Colômbia, na Costa Rica, nos Estados Unidos da América, na França, na Irlanda, em Israel, na Islândia, no Japão, em Malta, no Reino Unido, na Suíça etc.

A democracia representativa contemporânea, como defende María Ángeles Abellán López, apesar das tensões apresentadas, “[...] é a solução institucional para os problemas de compatibilidade [...]"71 entre o democratismo, o republicanismo e o li-

69 O'DONNELL, Guillermo. Accountability horizontal e novas poliarquias. Lua Nova, São Paulo, n. 44, p. 27-54, 1998. p. 34 .

70 ARAÚJO, Cícero. República e democracia. Lua Nova, São Paulo, n. 51, p. 5-30, 2000. p. 5.

71 ABELLÁN LÓPEZ, María Ángeles. El influjo de la tradición republicana en la democracia representativa contemporánea. Revista de La Facultad de Ciencias Sociales y Jurídicas, Elche, v. I, n. 10, p. 127-141, jul. 2014. p. 131 (tradução nossa). 
beralismo, pois ela equilibra o papel do Estado como uma instituição pública, a sua fundação liberal - afirmação de uma esfera de direitos protegidos de sua atuação -, o princípio da legitimidade democrática - aqueles que estão submetidos às normas são também sua fonte - e a subordinação de seus governantes ao primado da lei - como requer uma república.

Finalmente, sobre a combinação complexa dessas três tradições nas poliarquias reais, vale considerar as seguintes liçôes de Guillermo O’Donnell:

[...] o liberalismo atribui direitos defensivos aos indivíduos localizados na esfera privada; o republicanismo atribui obrigaçōes aos indivíduos que devem ser cumpridos na esfera pública; e a democracia afirma o direito positivo de participação nas decisões do demos.

Mas há uma convergência importante. A democracia em seus impulsos de igualação, o liberalismo com seu compromisso com a proteção das liberdades e o republicanismo em sua severa visão das obrigações daqueles que governam a sociedade, apoiam, cada qual a seu modo, outro aspecto fundamental da poliarquia e do Estado constitucional que deve coexistir com ela: o império da lei. Todos os cidadãos têm direitos iguais de participar da tomada de decisões coletivas dentro do quadro institucional existente; uma declaração democrática à qual se acrescenta o preceito republicano de que ninguém, inclusive aqueles que governam, deve estar acima da lei; e a salvaguarda liberal de que certas liberdades e garantias não devem ser infringidas ${ }^{72}$.

Pelo exposto, conclui-se que, além de terem sido formadas a partir da tensão entre o democratismo, o republicanismo e o liberalismo, as democracias representativas contemporâneas, para funcionar a contento, dependem da contínua interação entre essas tradições políticas.

Além da associação entre as tradições históricas, apresentada nesta seção, é evidente que a escala é um fator que diferencia muito as democracias contemporâneas de sua versão clássica. Com o crescimento das unidades políticas, cujo eixo se deslocou da cidade-estado ao Estado-nação, foi adotado o instituto da representação, do qual trata a seção seguinte deste trabalho.

\subsection{DEMOCRACIA, REPRESENTAÇÃO E ACCOUNTABILITY}

Diante das transformações históricas e da mudança de escala das sociedades contemporâneas, foi o influxo conjunto das tradiçôes democrática, republicana e liberal que tornou possível o sistema político que hoje se chama democracia, e que, provavelmente, não seria reconhecido como tal por um cidadão da Atenas clássica.

72 O’DONNELL, Guillermo. Accountability horizontal e novas poliarquias. Lua Nova, São Paulo, n. 44, p. 27-54, 1998. p. 33. 


\section{•- Contas dos governantes}

Isso porque, como recorda Robert Alan Dahl' ${ }^{73}$, na visão grega, uma ordem democrática teria que satisfazer, pelo menos, seis requisitos, quais sejam: (i) os interesses pessoais dos cidadãos deveriam ser harmoniosos; (ii) a composição da sociedade deveria ser homogênea; (iii) o número de cidadãos deveria ser pequeno; (iv) as decisões sobre as leis e sobre o governo deveriam caber diretamente aos cidadãos, sem representação; (v) a participação não deveria se limitar à assembleia, mas também ser extensiva à administração da cidade; e (vi) a cidade deveria ser autônoma. Não é difícil perceber que esses requisitos não são, e nem poderiam ser, satisfeitos pela absoluta maioria dos Estados nacionais atuais.

Assim, embora Frank Ankersmith destaque que "[...] a noção de democracia representativa não é menos monstruosa do que a de um templo gótico grego" 74 , o fato é que, como assevera Jon Elster, “[...] as democracias modernas [...] são sempre representativas" 75 . E nem poderia ser diferente, pois, como destaca Luís Felipe Miguel, "[...] constatar a impossibilidade da democracia direta nas sociedades contemporâneas é algo banal"76-77. Como explica,

Nossos estados são muito extensos para que todos reúnam-se e muito populosos para que se possa imaginar um diálogo que incorpore cada um de seus cidadãos. As questôes políticas são complexas demais para que dispensemos a especialização dos governantes e, por sua vez, os afazeres privados absorvem demais cada um de nós, reduzindo ao mínimo o tempo para a participação política. A incorporação de tantos grupos ao demos - trabalhadores, mulheres, imigrantes - ampliou a profundidade das clivagens em seu seio, tornando indispensável a existência de alguma forma de mediação. Enfim, seja qual for a justificativa, não resta dúvida

73 DAHL, Robert Alan. Democracy and its critics. New Haven: Yale University Press, 1989. p. 28-30.

74 ANKERSMIT, Frank. Democracia representativa. Antíteses, Londrina, v. 6, n. 12, p. 456-467, jul./ dez. 2013. p. 457 (tradução nossa).

75 ELSTER, Jon (Org.). Deliberative democracy. Cambridge: Cambridge University Press, 1998. p. 8 (tradução nossa).

76 MIGUEL, Luís Felipe. Impasses da accountability: dilemas e alternativas da representação política. Revista de Sociologia e Política, Curitiba, n. 25, p. 25-38, nov. 2005. p. 26.

77 A respeito da crescente aplicação de mecanismos de democracia direta nas democracias representativas, cf. PÁLLINGER, Zoltán Tibor; KAUFMANN, Bruno; MARXER, Wilfried; SCHILLER, Theo (Ed.). Direct democracy in Europe: developments and prospects. Wiesbaden: VS Verlag für Sozialwissenschaften, 2007; BOWLER, Shaun; GLAZER, Amihai. Direct democracy's impact on American political institutions. New York: Palgrave Macmillan, 2008; ALTMAN, David. Direct democracy worldwide. New York: Cambridge University Press, 2011; e ALTMAN, David. Citizenship and contemporary direct democracy. Cambridge: Cambridge University Press, 2019. A respeito da impossibilidade desses mecanismos substituírem a democracia representativa, cf. HASKELL, John. Direct democracy or representative government? Dispelling the populist myth. Oxford: Westview Press, 2001; e BAILEY, Lonce H.; MILEUR, Jerome M. In defense of the founders republic: critics of direct democracy in the Progressive Era. London: Bloomsbury Publishing, 2015. 
de que a representação política é incontornável para qualquer tentativa de construção da democracia nos estados nacionais contemporâneos ${ }^{78}$.

Desse modo, conforme Robert Alan Dahl, a representação é a mudança mais óbvia, em relação à antiga democracia, decorrente da mudança de escala do Estado e é "[...] adotada como um elemento essencial da democracia moderna” "79. Segundo ele, aceito o instituto, "[...] nenhum país poderia ser muito extenso, nenhuma população muito grande para um governo representativo"

Nesse contexto, a democracia - não olvidando de suas influências republicana e liberal - brasileira se organizou como representativa, conforme se depreende do parágrafo único do artigo $1^{\circ} \mathrm{da} C R F B / 1988$, que estabelece que "Todo o poder emana do povo, que o exerce por meio de representantes eleitos ou diretamente, nos termos desta Constituição" ${ }^{\text {. }}$. E nem poderia ser diferente ante a população e extensão de um país com mais de duzentos milhôes de habitantes, distribuídos em mais de oito milhôes e quinhentos mil $\mathrm{km}^{2} 82$.

Contudo, se a necessidade de representação no sistema democrático atual parece evidente, o mesmo não pode ser dito em relação ao significado do que é representar. É o que destacam Adam Przeworski, Susan C. Stokes e Bernard Manin quando afirmam que "O significado da representação é notoriamente contestado. Além da noção de que representar implica agir no interesse do representado, parece haver pouco mais no qual os teóricos concordam" 83 . Porém, a despeito dessa divergência, a noção consensual, sobre a necessidade de agir no interesse do representado, para que se possa dizer que há representação, é suficiente para os objetivos deste trabalho ${ }^{84}$.

78 MIGUEL, Luís Felipe. Impasses da accountability: dilemas e alternativas da representação política. Revista de Sociologia e Política, Curitiba, n. 25, p. 25-38, nov. 2005. p. 26.

79 DAHL, Robert Alan. Democracy and its critics. New Haven: Yale University Press, 1989. p. 215 (tradução nossa).

80 DAHL, Robert Alan. Democracy and its critics. New Haven: Yale University Press, 1989. p. 217 (tradução nossa).

81 BRASIL. Constituição (1988). Constituição da República Federativa do Brasil. Disponível em: http:// www.planalto.gov.br/ccivil_03/Constituicao/Constituicao.htm. Acesso em: 2 dez. 2019.

82 Em $1^{\circ}$ de julho de 2020, a população brasileira seria de 211.755.692 de habitantes, numa área de $8.510 .820,623 \mathrm{~km}^{2}$, cf. INSTITUTO BRASILEIRO DE GEOGRAFIA E ESTATÍSTICA. Estatísticas. Sociais. População. Projeção da população: 2018. Disponível em: https://www.ibge.gov.br/estatisticas-novoportal/sociais/populacao/9109-projecao-da-populacao.html?=\&t=downloads. Acesso em: 16 out. 2019; e INSTITUTO BRASILEIRO DE GEOGRAFIA E ESTATÍSTICA. Estatísticas. Geociências. Organização do território. Estrutura territorial. Áreas dos municípios. Disponível em: https://www.ibge.gov.br/geociencias/organizacao-do-territorio/estrutura-territorial/15761-areas-dos-municipios.html?=\&t=o-que-e. Acesso em: 16 out. 2019.

83 PRZEWORSKI, Adam; STOKES, Susan C.; MANIN, Bernard (Org.). Introduction. In: Democracy, accountability, and representation. Cambridge: Cambridge University Press, 1999. p. 2 (tradução nossa).

84 A respeito do significado do que é representar, cf. URBINATI, Nadia. Representative democracy: principles and genealogy. Chicago: University of Chicago Press, 2006; e URBINATI, Nadia. O que torna a representação democrática? Lua Nova, São Paulo. n. 67, p. 191-228, 2006. 


\section{-. Contas dos governantes}

Apesar dos méritos que lhe são devidos como a solução que tornou a democracia - republicana e liberal - possível em grande escala, Luís Felipe Miguel ${ }^{85}$, com preocupação, destaca que a representação política gera, inevitavelmente, ao menos, três problemas fundamentais, a saber: (i) as decisões são tomadas por um pequeno grupo, não pela maioria; (ii) a rotatividade dos representantes é baixa; e (iii) ocorre um distanciamento entre as vontades dos representantes e dos representados.

Então, como forma de mitigar os riscos envolvidos na adoção do instituto da representação, Guillermo O’Donnell ${ }^{86}$ defendia que a representação implica accountability.

Para Luís Felipe Miguel ${ }^{87}$, a accountability é uma resposta das instituições democráticas aos problemas causados pela representação. Semelhantemente, Ana Carolina Yoshida Hirano de Andrade Mota a defende como "[...] um mecanismo que conduz à implementação da representação, pois força os representantes a agirem no melhor interesse público" 88 .

Segundo Guillermo O’Donnell ${ }^{89}$, de algum modo, os representantes devem ser responsabilizados por suas ações perante aqueles que eles representam. María Ángeles Abellán López concorda com ele quando afirma que "Para funcionar corretamente, a democracia representativa precisa que os governantes sejam responsabilizados por suas açōes perante os cidadãos, e requer que estes monitorem seus representantes políticos" ${ }^{\prime 0}$.

Scott Mainwaring vai além ao asseverar que "A democracia não pode existir sem accountability" 91 . Outrossim, conforme Francis Fukuyama, a accountability democrática é uma das três instituições básicas das democracias liberais modernas e "[...] procura garantir que o governo atue no interesse de toda a comunidade, e não simplesmente no interesse próprio dos governantes" ${ }^{92}$.

85 MIGUEL, Luís Felipe. Impasses da accountability: dilemas e alternativas da representação política. Revista de Sociologia e Política, Curitiba, n. 25, p. 25-38, nov. 2005. p. 26-27.

86 O'DONNELL, Guillermo. Delegative democracy. Journal of Democracy, Washington, v. 5, n. 1, p. 55-69, Jan. 1994. p. 61-62.

87 MIGUEL, Luís Felipe. Impasses da accountability: dilemas e alternativas da representação política. Revista de Sociologia e Política, Curitiba, n. 25, p. 25-38, nov. 2005. p. 27.

88 MOTA, Ana Carolina Yoshida Hirano de Andrade. Accountability no Brasil: os cidadãos e seus meios institucionais de controle dos representantes. 2006. 243 f. Tese (Doutorado em Ciência Política) - Departamento de Ciência Política, Faculdade de Filosofia, Letras e Ciências Humanas, Universidade de São Paulo, São Paulo, 2006. f. 232.

89 O’DONNELL, Guillermo. Delegative democracy. Journal of Democracy, Washington, v. 5, n. 1, p. 55-69, Jan. 1994. p. 61.

90 ABELLÁN LÓPEZ, María Ángeles. El influjo de la tradición republicana en la democracia representativa contemporánea. Revista de La Facultad de Ciencias Sociales y Jurídicas, Elche, v. I, n. 10, p. 127-141, jul. 2014. p. 137 (tradução nossa).

91 MAINWARING, Scott. Introdução: Democratic accountability in Latin America. In: MAINWARING, Scott; WELNA, Christoper. Democratic accountability in Latin America. New York: Oxford University Press, 2003. p. 29 (tradução nossa).

92 FUKUYAMA, Francis. Why is democracy performing so poorly? Journal of Democracy, Washington, v. 26, n. 1, p. 11-20, 2015. p. 12 (tradução nossa). 
Ainda, Fernando Luiz Abrucio e Maria Rita Loureiro ensinam que a obrigação dos governantes de "[...] prestar contas ao povo, responsabilizando-se perante ele, pelos atos ou omissões cometidos no exercício do poder" ${ }^{93}$, é um dos princípios orientadores da democracia. Na verdade, essa necessidade de permanente vigilância e controle sobre os poderes políticos, como ensina María Ángeles Abellán López ${ }^{94}$, é expressão da tradição republicana nas democracias representativas contemporâneas.

Pelo exposto nesta seção, conclui-se que, apesar de estranho à tradição histórica democrática, o instituto da representação, bem recebido nas democracias representativas contemporâneas em razão da influência conjunta das tradições republicana e liberal, é essencial ao funcionamento do sistema político na escala do Estado-nação. Entretanto, como consequência do influxo dos ideais republicanos e democráticos, a adoção da representação carrega consigo a exigência de accountability, cujo significado é discutido na seção seguinte.

\subsection{O SIGNIFICADO DE ACCOUNTABILITY}

Jeremy Waldron ${ }^{95}$ defende que o conceito de accountability deve considerar a ideia republicana fundamental de que os negócios do governo são negócios públicos, em conjunto com a convicção democrática de que os membros da comunidade política têm o direito a supervisionar, até mesmo diretamente, a conduta dos governantes.

Numa relação de accountability, de acordo com Scott Mainwaring ${ }^{96}$, determinado agente público presta contas de suas ações e omissões àqueles que o direito público tenha formalmente atribuído a capacidade de lhe exigir a prestação de contas e/ou lhe impor sanções. Nesse aspecto, como aplicação das lições de Richard Mulgan ${ }^{97}$, se os governantes têm o dever de prestar contas, então aqueles perante quem as contas são prestadas possuem o direito de exigi-las.

93 ABRUCIO, Fernando Luiz; LOUREIRO, Maria Rita. Finanças públicas, democracia e accountability. In: ARVATE, Paulo Roberto; BIDERMAN, Ciro (Org.). Economia do setor público no Brasil. Rio de Janeiro: Elsevier/Campus, 2004. p. 81.

94 ABELLÁN LÓPEZ, María Ángeles. El influjo de la tradición republicana en la democracia representativa contemporánea. Revista de La Facultad de Ciencias Sociales y Jurídicas, Elche, v. I, n. 10, p. 127-141, jul. 2014. p. 134.

95 WALDRON, Jeremy. Accountability: fundamental to democracy. School of Law, New York University. New York: New York School of Law, 2014. (Public Law \& Legal Theory Reserch Paper Series; Working Paper n. 14-13, Apr. 2014). p. 19.

96 MAINWARING, Scott. Introdução: Democratic accountability in Latin America. In: MAINWARING, Scott; WELNA, Christoper. Democratic accountability in Latin America. New York: Oxford University Press, 2003. p. 7 (tradução nossa).

97 MULGAN, Richard. The processes of public accountability. Australian Journal of Public Administration, v. 56, n. 1, p. 25-36, Mar. 1997. p. 27 (tradução nossa). 
Andreas Schedler ${ }^{98}$ conceitua a accountability como a junção de dois pilares distintos, a saber, da answerability com o enforcement. $\mathrm{O}$ primeiro pilar, segundo ele, exige que os agentes públicos tanto apresentem informações sobre suas ações e omissões como expliquem suas motivações, envolvendo, portanto, uma dimensão informativa e outra argumentativa. Mark Bovens ${ }^{99}$ explica que o responsável, nesse tipo de relação, sente-se obrigado a explicar e justificar publicamente sua conduta perante um agente específico.

Sobre a exigência do segundo pilar, como ensina Andreas Schedler ${ }^{100}$, a accountability envolve mais do que a geração de dados e outras informações e a apresentação de argumentos, pois, para que exerça sua função de limitação real ao exercício do poder - tornando-o previsível, limitando sua arbitrariedade e prevenindo ou reparando seu abuso -, os agentes de accountability devem possuir capacidade de impor sançóes aos agentes públicos que violem suas obrigações. Nesse sentido, Scott Mainwaring ${ }^{101}$ afirma que também o enforcement, em complemento à answerability, é exigido para se ter accountability.

Embora Andreas Schedler ${ }^{102}$ considere que, em alguns casos - por exemplo, quando a exposição pública e a destruição da reputação dela decorrente constituem verdadeira punição ao responsabilizado -, a answerability pode suprir a falta de enforcement e constituir-se em verdadeira accountability - tal posicionamento é, inclusive destacado por ele em trabalho conjunto com Larry Diamond e Marc F. Plattner ${ }^{103}$-, neste trabalho consideram-se mais acertadas as posiçôes de Delmer D. Dunn ${ }^{104}$ e Charles D.

98 SCHEDLER, Andreas. Conceptualizing accountability. In: SCHEDLER, Andreas; DIAMOND, Larry; PLATTNER, Marc F. The self-restraining state: power and accountability in new democracies. Boulder: Lynne Rienner Publishers, 1999. p. 14-15.

99 BOVENS, Mark. Public accountability. In: FERLIE, Ewan; LYNN, Laurence E.; POLLITT, Christopher. The Oxford Handbook of Public Management. New York: Oxford University Press, 2005. p. 182-208. Disponível em: http://dspace.library.uu.nl/handle/1874/15015. Acesso em: 23 jan. 2017. p. 185.

100 SCHEDLER, Andreas. Conceptualizing accountability. In: SCHEDLER, Andreas; DIAMOND, Larry; PLATTNER, Marc F. The self-restraining state: power and accountability in new democracies. Boulder: Lynne Rienner Publishers, 1999. p. 15-16; 18-19.

101 MAINWARING, Scott. Introdução: Democratic accountability in Latin America. In: MAINWARING, Scott; WELNA, Christoper. Democratic accountability in Latin America. New York: Oxford University Press, 2003. p. 7.

102 SCHEDLER, Andreas. Conceptualizing accountability. In: SCHEDLER, Andreas; DIAMOND, Larry; PLATTNER, Marc F. The self-restraining state: power and accountability in new democracies. Boulder: Lynne Rienner Publishers, 1999. p. 16-17.

103 SCHEDLER, Andreas; DIAMOND, Larry; PLATTNER, Marc F. Introduction. In: The self-restraining state: power and accountability in new democracies. Boulder: Lynne Rienner Publishers, 1999. p. 4.

104 DUNN, Delmer D. Mixing elected and nonelected officials in democratic policy making: fundamentals of accountability and responsibility. In: PRZEWORSKI, Adam; STOKES, Susan C.; MANIN, Bernard (Org.). Democracy, accountability, and representation. Cambridge: Cambridge University Press, 1999. p. 299. 
Kenney ${ }^{105}$, que entendem que o conceito de accountability implica necessariamente a capacidade de aplicação de sanções ou atribuições de prêmios.

Convém destacar, como o faz Scott Mainwaring ${ }^{106}$, que não há exigência de que o poder sancionatório seja direto, sendo suficiente que o agente de accountability tenha a competência para apresentar a situação punível a outros atores que detenham a capacidade de impor sanções. Além disso, deve-se ressaltar que a sanção, como defende Arlindo Carvalho Rocha ${ }^{107}$, pode ter natureza legal ou moral.

Tanto Jon Elster ${ }^{108}$ como Erika Moreno, Brian F. Crisp e Mathew Søberg Shugart $^{109}$ abordam o conceito de accountability sob a perspectiva da relação de agência principal-agent. Segundo os últimos, somente se pode falar em accountability entre aqueles que estejam numa das pontas daquela relação, desempenhando o papel de principal, ou o de agente. Nessa ótica, o principal manteria sempre a possibilidade de retirar o agente de seu papel, seja pela demissão, seja pela não renovação do mandato.

James D. Fearon, também, iguala a accountability entre dois atores às "[...] relações de agência em que uma parte é entendida como um 'agente', que faz algumas escolhas em nome de um 'principal', que tem poderes para sancionar ou recompensar o agente" 110 .

A relação de agência, convém apresentar, é pesquisada no âmbito da teoria da agência, cujos trabalhos seminais são de Barry M. Mitnick e Stephen Alan Ross. Segundo este, que considerava a relação entre o Estado e os governados como uma relação de agência, "Dir-se-á que uma relação de agência surgiu entre duas (ou mais) partes quando uma, designada como agente, age por, em nome ou como representante da outra, designada principal, com autoridade de decisão num determinado

105 KENNEY, Charles D. Horizontal accountability: concepts and conflicts. In: MAINWARING, Scott; WELNA, Christoper. Democratic accountability in Latin America. New York: Oxford University Press, 2003. p. 63.

106 MAINWARING, Scott. Introdução: Democratic accountability in Latin America. In: MAINWARING, Scott; WELNA, Christoper. Democratic accountability in Latin America. New York: Oxford University Press, 2003. p. 12-13.

107 ROCHA, Arlindo Carvalho. A realização da accountability em pareceres prévios do Tribunal de Contas de Santa Catarina. Revista de Administração Pública, Rio de Janeiro, v. 47, n. 4, p. 901-926, jul./ago. 2013. p. 904.

108 ELSTER, Jon. Accountability in Athenian politics. In: PRZEWORSKI, Adam; STOKES, Susan C.; MANIN, Bernard (Org.). Democracy, accountability, and representation. Cambridge: Cambridge University Press, 1999. p. 254-255.

109 MORENO, Erika; CRISP, Brian F.; SHUGART, Mathew Søberg. The accountability deficit in Latin America. In: MAINWARING, Scott; WELNA, Christoper. Democratic accountability in Latin America. New York: Oxford University Press, 2003. p. 82; 84.

110 FEARON, James D. Electoral accountability and the control of politicians: selecting good types versus sanctioning poor performance. In: PRZEWORSKI, Adam; STOKES, Susan C.; MANIN, Bernard (Org.). Democracy, accountability, and representation. Cambridge: Cambridge University Press, 1999. p. 55 (tradução nossa). 
domínio"111. Barry M. Mitnick ${ }^{112}$ destaca que a relação de agência tem o objetivo de beneficiar o principal e que a formação daquela exige o consentimento deste.

Contudo, como destacaram Michael C. Jensen e William H. Meckling, "Se ambas as partes da relação são maximizadoras de utilidade há boas razões para acreditar que o agente nem sempre vai agir no melhor interesse do principal" 113 , tornando necessários tanto a criação de incentivos ao bom comportamento do agente como o monitoramento de suas atividades.

A teoria da agência, como ensina Kathleen M. Eisenhardt ${ }^{114}$, preocupa-se, especialmente, com as situações nas quais a criação de incentivos ao agente e/ou o monitoramento de suas atividades são muito custosas para o principal. Além desse, outro problema, segundo ela, envolve a partilha de riscos entre o agente e o principal, e ocorre quando suas diferentes preferências de riscos os levam a divergir sobre a melhor ação a ser adotada. Nessas situações, como explica Pedro Ary Malato Borrato Ferreira da Cunha, num problema potencializado pela assimetria de informação entre agente e principal, muitas vezes, como detêm os poderes de gestão da atividade, "[...] os interesses dos primeiros levam a melhor sobre os interesses dos segundos" $" 115$.

Esclarecendo a ligação entre a relação de agência e a accountability, John Ferejohn ${ }^{116}$ apresenta o ramo da teoria da agência denominado teoria da soberania popular, segundo o qual o povo constitui o governo - nacional ou regional - e lhe delega alguns de seus poderes, submetendo o exercício desses poderes, contudo, a contínua supervisão direta e indireta. A submissão a tal vigilância nada mais é do que sujeição à accountability.

Assim, Pedro Ary Malato Borrato Ferreira da Cunha ${ }^{117}$ defende a existência de uma relação de agência entre os cidadãos e os representantes políticos - inclusive os

111 ROSS, Stephen Alan. The economic theory of agency: the principal's problem. The American Economic Review, Pittsburgh, v. 63, n. 2, p. 134-139, May 1973. Disponível em: http://www.jstor.org/stable/1817064. Acesso em: 21 fev. 2017. p. 134. (Papers and Proceedings of the Eighty-fifth Annual Meeting of the American Economic Association) (tradução nossa).

112 MITNICK, Barry M. Fiduciary rationality and public policy: the theory of agency and some consequences. In: ANNUAL MEETING OF THE AMERICAN POLITICAL SCIENCE ASSOCIATION, 1973, New Orleans. Proceedings... New Orleans: American Political Science Association, 1973. DOI: $10.2139 /$ ssrn.1020859. p. 1-2.

113 JENSEN, Michael C.; MECKLING, William H. Theory of the firm: managerial. Journal of Financial Economics, Rochester, v. 3, p. 305-360, 1976. DOI: 10.1016/0304-405X(76)90026-X. p. 308.

114 EISENHARDT, Kathleen M. Agency theory: an assessment and review. Academy of Management Review, Briarcliff Manor, v. 14, n. 1, p. 57-74, 1989. p. 58.

115 CUNHA, Pedro Ary Malato Borrato Ferreira da. Políticas de combate à corrupção: corrupção no setor público sob a perspetiva da teoria da agência. 2012. 180 f. Dissertação (Mestrado em Direito) Faculdade de Direito, Universidade do Porto, Porto, 2012. f. 22.

116 FEREJOHN, John. Accountability and authority: toward a theory of political accountability. In: PRZEWORSKI, Adam; STOKES, Susan C.; MANIN, Bernard (Org.). Democracy, accountability, and representation. Cambridge: Cambridge University Press, 1999. p. 134-136.

117 CUNHA, Pedro Ary Malato Borrato Ferreira da. Políticas de combate à corrupção: corrupção no setor público sob a perspetiva da teoria da agência. 2012. 180 f. Dissertação (Mestrado em Direito) Faculdade de Direito, Universidade do Porto, Porto, 2012. f. 30-31. 
chefes de governo -, no exercício, respectivamente, dos papéis de principais e agentes. Nessa relação, como observa, há: (i) delegação de poderes; (ii) designação mediante processo competitivo - eleições; (iii) assimetria de informação; e (iv) divergência de interesses. Desse modo, ele defende que tal relação deve vir acompanhada das seguintes cláusulas:

a) O controlo último deve residir no principal, que corre os riscos;

b) Para manter o controlo o principal deve procurar aumentar a qualidade da informação disponível e diminuir os custos de aceder a esta, de forma a diminuir as assimetrias de informação e assim diminuir os riscos de seleção adversa e risco moral;

c) Com esse objetivo o principal pode apontar diversos agentes que se controlem mutuamente, de forma a que os interesses privados sejam detetados nesse controlo ou se anulem na competição;

d) $\mathrm{O}$ agente tem liberdade para prosseguir da melhor forma o interesse do principal, mas é responsável na medida dessa liberdade, pelo que a discricionariedade que detém corresponde a um vínculo absoluto em tomar aquela que considera ser a melhor decisão para uma noção de bem comum assente nas preferências manifestadas pelos indivíduos, dentro das que se encontram disponíveis nos termos do Direito;

e) A delegação de poderes caduca com o tempo, mas é prorrogável mediante avaliações periódicas pelo principal ${ }^{118}$.

Veja-se que, conforme apresentado no transcrito item "c", Pedro Ary Malato Borrato Ferreira da Cunha, diferentemente de Erika Moreno, Brian F. Crisp e Mathew Søberg Shugart, aponta a compatibilidade entre a relação de agência e a designação, pelo principal, de outros atores com a função de controlar os agentes e o intuito de preservar o seu interesse, inclusive com melhora da qualidade da informação disponível, redução da assimetria de informação e redução dos riscos de seleção adversa e moral.

Perceba-se que a designação de um terceiro personagem, para o exercício do controle, estende subjetivamente a accountability além daqueles que exercem os papéis de agente e principal da relação de agência original. Tal constatação é corroborada por Scott Mainwaring ${ }^{119}$, Guillermo O’Donnell ${ }^{120}$ e Charles D. Kenney ${ }^{121}$, quando explicam que a

118 CUNHA, Pedro Ary Malato Borrato Ferreira da. Políticas de combate à corrupção: corrupção no setor público sob a perspetiva da teoria da agência. 2012. 180 f. Dissertação (Mestrado em Direito) Faculdade de Direito, Universidade do Porto, Porto, 2012. f. 31.

119 MAINWARING, Scott. Introdução: Democratic accountability in Latin America. In: MAINWARING, Scott; WELNA, Christoper. Democratic accountability in Latin America. New York: Oxford University Press, 2003. p. 15.

120 O'DONNELL, Guillermo. Horizontal accountability: the legal institutionalization of mistrust. In: MAINWARING, Scott; WELNA, Christoper. Democratic accountability in Latin America. New York: Oxford University Press, 2003. p. 35. 


\section{•. Contas dos governantes}

relação de accountability não está limitada aos atores que se encontram nos polos da relação de agência. É o que ocorre, como exemplifica Mark Bovens ${ }^{122}$, nas relações de prestação de contas administrativas - tribunais de contas, controladorias, auditorias independentes etc. -, que não se enquadram nas clássicas relações entre principais e agentes.

Conclui-se, portanto, que, embora sempre decorra - imediata ou mediatamente de uma relação de agência, a accountability nem sempre se dá entre o principal e o agente daquela relação, existindo situações em que o agente de responsabilização, ou agente de accountability, é ator diverso do principal.

Richard Mulgan ${ }^{123}$ observa que a accountability, na medida em que obriga o responsável a prestar contas de suas açôes e omissóes, limita a sua discricionariedade. Esse é um fator considerado por Ana Carolina Yoshida Hirano de Andrade Mota, que conceitua a accountability como um mecanismo de controle que coage agentes com múnus público "[...] a explicar seus atos discricionários, tornando públicas as suas motivações, quando provocados institucionalmente, sob pena de punição legal"124. Contudo, como adverte Andreas Schedler, a accountability não tem o intuito de

[...] eliminar a discricionariedade mediante uma rigorosa regulamentação burocrática. É um projeto mais modesto que admite que a política é uma atividade humana cujos elementos de agência, liberdade, indeterminação e incerteza não lhe são erradicáveis; Que o poder não pode estar sujeito ao pleno controle no sentido estrito e técnico da palavra; E que, mesmo em um mundo hipotético de perfeita accountability, o poder político continuaria a produzir danos, desperdícios e qualquer outro tipo de irreversíveis "males públicos" que até mesmo os agentes ideais de accountability só poderiam determinar, expor e punir, contudo sem capacidade para reparar ou desfazer ${ }^{125}$.

Neste trabalho, considerando a influência das tradições democrática, republicana e liberal nas democracias representativas contemporâneas, conceitua-se analitica-

121 KENNEY, Charles D. Horizontal accountability: concepts and conflicts. In: MAINWARING, Scott; WELNA, Christoper. Democratic accountability in Latin America. New York: Oxford University Press, 2003. p. 57.

122 BOVENS, Mark. Public accountability. In: FERLIE, Ewan; LYNN, Laurence E.; POLLITT, Christopher. The Oxford Handbook of Public Management. New York: Oxford University Press, 2005. Disponível em: http://dspace.library.uu.nl/handle/1874/15015. Acesso em: 23 jan. 2017. p. 196-198.

123 MULGAN, Richard. The processes of public accountability. Australian Journal of Public Administration, v. 56, n. 1, p. 25-36, mar. 1997. p. 27 (tradução nossa).

124 MOTA, Ana Carolina Yoshida Hirano de Andrade. Accountability no Brasil: os cidadãos e seus meios institucionais de controle dos representantes. 2006. 243 f. Tese (Doutorado em Ciência Política) - Departamento de Ciência Política, Faculdade de Filosofia, Letras e Ciências Humanas, Universidade de São Paulo, São Paulo, 2006. f. 58.

125 SCHEDLER, Andreas. Conceptualizing accountability. In: SCHEDLER, Andreas; DIAMOND, Larry; PLATTNER, Marc F. The self-restraining state: power and accountability in new democracies. Boulder: Lynne Rienner Publishers, 1999. p. 19-20 (tradução nossa). 
mente - não ignorando os riscos que se assume quando se propõe a apresentar um conceito próprio - a relação de accountability pública como aquela, decorrente de uma relação de agência, mas não limitada aos atores que nela exercem os papéis de agente e principal, em que um ou mais agentes públicos, a quem foram formalmente delegados poderes para o exercício de atividades públicas, são limitados em sua discricionariedade, na medida em que têm a obrigação de prestar contas de suas ações e omissões incluindo tanto a prestação de informações propriamente ditas como a apresentação de argumentos que justifiquem a sua atuação - a determinados, um ou mais, agentes de accountability - que têm o direito de exigi-las, apesar de não necessariamente coincidirem com a figura do principal da relação de agência envolvida -, os quais detêm a capacidade, direta ou indireta, mediante a apresentação da situação punível a outros atores que detenham a capacidade direta, de impor sançôes, ou conceder premiações, jurídicas, políticas ou morais aos responsabilizados.

Tal conceito, é importante destacar, refere-se a todos os campos de atuação dos agentes públicos, em geral, e dos governantes, em particular. Não se limita, portanto, à accountability sobre a gestão financeira e orçamentária da Administração Pública a seu encargo, que é tratada, de forma específica, no capítulo 2 (p. 71) deste trabalho.

Com a definição, nesta seção, do significado de accountability, com a apresentação de seu conceito, resta, neste capítulo 1, tratar de suas dimensões, o que se faz na próxima seção.

\subsection{DIMENSÕES DA ACCOUNTABILITY}

Neste trabalho, adota-se a célebre classificação de Guillermo O’Donnell126 e se divide a accountability pública em vertical e horizontal ${ }^{127}$. Ela se baseia na condição de

126 O’DONNELL, Guillermo. Delegative democracy. Journal of Democracy, Washington, v. 5, n. 1, p. 55-69, Jan. 1994. p. 61-62.

127 Considera-se que a classificação proposta por Guillermo O’Donnel, além de didática, útil e simples, foi suficientemente posta à prova e manteve o seu valor, como defendeu e demonstrou o próprio autor. Por exemplo, ela foi objeto dos trabalhos, análises e críticas de Philippe C. Schmitter, Catalina Smulovitz e Enrique Peruzzotti, Scott Mainwaring - que propõe a divisão entre accountability eleitoral e intraestatal -, Charles D. Kenney, Erika Moreno, Brian F. Crisp e Mathew Søberg Shugart e Fernando Luiz Abrucio e Maria Rita Loureiro - e sua divisão entre processo eleitoral, controle institucional durante o mandato e regras estatais intertemporais -, cf. SCHMITTER, Philippe C. The limits of horizontal accountability. In: SCHEDLER, Andreas; DIAMOND, Larry; PLATTNER, Marc F. The self-restraining state: power and accountability in new democracies. Boulder: Lynne Rienner Publishers, 1999. p. 59 62; SMUlOVITZ, Catalina; PERUZZOTTI, Enrique. Societal accountability in Latin America. Journal of Democracy, Washington, v. 11, n. 4, p. 147-158, 2000. p. 148-153; MAINWARING, Scott. Introdução: Democratic accountability in Latin America. In: MAINWARING, Scott; WELNA, Christoper. Democratic accountability in Latin America. New York: Oxford University Press, 2003. p. 18-20; KENNEY, Charles D. Horizontal accountability: concepts and conflicts. In: MAINWARING, Scott; WELNA, Christoper. Democratic accountability in Latin America. New York: Oxford University Press, 2003. p. 60-62; MORENO, Erika; CRISP, Brian F.; SHUGART, Mathew Søberg. The accountability deficit in Latin America. In: MAINWARING, Scott; WELNA, Christoper. 


\section{•. Contas dos governantes}

o sujeito ativo - neste trabalho é tomado como tal aquele que responsabiliza - da accountability pertencer ou não à estrutura estatal. Assim, enquanto o sujeito ativo da accountability vertical não pertence à estrutura do Estado, na horizontal as contas são prestadas perante outro agente governamental.

\subsubsection{Accountability vertical}

Desde que a representação política foi instituída, sua estrutura básica, invariavelmente, como destacam Adam Przeworski, Susan C. Stokes e Bernard Manin ${ }^{128}$, envolve a seleção dos governantes por meio de eleições periódicas. Tais eleições, segundo Scott Mainwaring ${ }^{129}$ e Jeremy Waldron ${ }^{130}$, são não somente um aspecto importante, mas o principal meio da accountability vertical imaginada por Guillermo O’Donnell.

Aliás, se é possível indicar determinado país como uma poliarquia, tem-se por definição, como argumentava Guillermo O’Donnell'131, a realização de eleições periódicas razoavelmente livres e justas, nas quais os eleitores podem votar nos governantes, ou nos candidatos que eles apoiam, premiando-os; ou contra eles, punindo-os. É o que ele denomina de dimensão eleitoral da accountability vertical.

Além de eleições, Guillermo O’Donnell inclui na dimensão vertical da accountability as "[...] reivindicações sociais que possam ser normalmente proferidas, sem que se corra o risco de coerção, e cobertura regular pela mídia ao menos das mais visíveis dessas reivindicações e de atos supostamente ilícitos de autoridades públicas"132, o que só é possível graças às liberdades de expressão e associação e ao acesso a diferentes

Democratic accountability in Latin America. New York: Oxford University Press, 2003. p. 85-91; e ABRUCIO, Fernando Luiz; LOUREIRO, Maria Rita. Finanças públicas, democracia e accountability. In: ARVATE, Paulo Roberto; BIDERMAN, Ciro (Org.). Economia do setor público no Brasil. Rio de Janeiro: Elsevier/Campus, 2004. p. 81-86; em resposta às críticas que recebeu, cf. O'DONNELL, Guillermo. A response to my commentators. In: SCHEDLER, Andreas; DIAMOND, Larry; PLATTNER, Marc F. The self-restraining state: power and accountability in new democracies. Boulder: Lynne Rienner Publishers, 1999. p. 68-69; e O’DONNELL, Guillermo. Horizontal accountability: the legal institutionalization of mistrust. In: MAINWARING, Scott; WELNA, Christoper. Democratic accountability in Latin America. New York: Oxford University Press, 2003. p. 34-36.

128 PRZEWORSKI, Adam; STOKES, Susan C.; MANIN, Bernard (Org.). Introduction. In: Democracy, accountability, and representation. Cambridge: Cambridge University Press, 1999. p. 3.

129 MAINWARING, Scott. Introdução: Democratic accountability in Latin America. In: MAINWARING, Scott; WELNA, Christoper. Democratic accountability in Latin America. New York: Oxford University Press, 2003. p. 18-19.

130 WALDRON, Jeremy. Accountability: fundamental to democracy. School of Law, New York University. New York: New York School of Law, 2014. (Public Law \& Legal Theory Reserch Paper Series; Working Paper n. 14-13, apr. 2014). p. 14-15.

131 O'DONNELL, Guillermo. Accountability horizontal e novas poliarquias. Lua Nova, São Paulo, n. 44, p. 27-54, 1998. p. 28.

132 O'DONNELL, Guillermo. Accountability horizontal e novas poliarquias. Lua Nova, São Paulo, n. 44, p. $27-54,1998$. p. 28. 
fontes de informação, instituições obrigatórias das poliarquias de Robert Alan Dahl, como se apresenta no início deste capítulo 1 (p. 39).

Guillermo O’Donnell ${ }^{133}$ também reconheceu como vertical a accountability social, identificada por Catalina Smulovitz e Enrique Peruzzotti, “[...] que se baseia nas ações de um conjunto múltiplo de associações e movimentos de cidadãos e na mídia, açôes que visam expor as irregularidades governamentais, inserir novos temas na agenda pública ou ativar as agências horizontais"134.

Contudo, nas democracias representativas contemporâneas, deve-se considerar, como fazem Adam Przeworski, Susan C. Stokes e Bernard Manin, que, ainda que os eleitores sejam livres para discutir as políticas públicas, criticar as ações tomadas pelos governantes e exigir continuamente que determinadas políticas sejam implementadas, "[...] eles não são capazes de dar instruçôes juridicamente vinculativas para o governo" 135 . Com isso, como destaca Andrew Arato, a sua capacidade de exigir que os representantes ajam em seu melhor interesse e prestem contas de suas ações, respondendo por elas, "[...] é tornar tais atitudes de interesse do próprio representante"136, levando-as em conta nas eleições seguintes, numa avaliação retrospectiva. De fato, como assevera Luís Felipe Miguel, a accountability vertical

[...] diz respeito à capacidade que os constituintes têm de impor sanções aos governantes, notadamente reconduzindo ao cargo aqueles que se desincumbem bem de sua missão e destituindo os que possuem desempenho insatisfatório. Inclui a prestação de contas dos detentores de mandato e o veredicto popular sobre essa prestação de contas ${ }^{137}$.

A partir das lições de Adam Przeworski, Susan C. Stokes e Bernard Manin, conclui-se que, embora os eleitores não tenham capacidade de impedir que os governantes e demais representantes tomem quaisquer medidas que vão de encontro aos seus interesses, eles podem mitigar esse risco se puderem incutir naqueles que os representam o sentimento de que há boa probabilidade de que eles tenham que prestar contas, nas eleições seguintes, por suas ações passadas.

133 O'DONNELL, Guillermo. Horizontal accountability: the legal institutionalization of mistrust. In: MAINWARING, Scott; WELNA, Christoper. Democratic accountability in Latin America. New York: Oxford University Press, 2003. p. 47-48.

134 SMULOVITZ, Catalina; PERUZZOTTI, Enrique. Societal accountability in Latin America. Journal of Democracy, Washington, v. 11, n. 4, p. 147-158, 2000.

135 PRZEWORSKI, Adam; STOKES, Susan C.; MANIN, Bernard (Org.). Introduction. In: Democracy, accountability, and representation. Cambridge: Cambridge University Press, 1999. p. 3 (tradução nossa).

136 ARATO, Andrew. Representação, soberania popular e accountability. Lua Nova, São Paulo, n. 55/56, p. 85-103, 2002. p. 91-92.

137 MIGUEL, Luís Felipe. Impasses da accountability: dilemas e alternativas da representação política. Revista de Sociologia e Política, Curitiba, n. 25, p. 25-38, nov. 2005. p. 27-28. 


\section{•. Contas dos governantes}

Assim, como destacam os mencionados autores, há accountability na representação quando "(1) os eleitores votam para manter o representante apenas quando este age em seu melhor interesse, e (2) o representante escolhe as políticas necessárias para ser reeleito"138. Eles ensinam ainda que, em um modelo puro de accountability, “[...] os eleitores usam o voto apenas para um propósito, qual seja, sancionar o titular; Além disso, está disponível aos eleitores toda a informação sobre o desempenho do titular"139.

Isso condiz com as lições de José María Maravall, segundo quem "Os governos democráticos são accountable quando os cidadãos podem julgar seu registro retrospectivamente no momento da eleição e puni-los ou recompensá-los adequadamente"140. A maior sanção, em se tratando de accountability vertical, como adverte Delmer D. Dunn $^{141}$, é justamente a retirada de apoio nas eleições seguintes, com a não eleição do próprio governante ou de quem ele apoia para o cargo.

Porém, como destacam Adam Przeworski, Susan C. Stokes e Bernard Manin ${ }^{142}$, os eleitores não utilizam as eleições periódicas apenas para essa avaliação retrospectiva, responsabilizando os representantes, reconduzindo ao cargo aqueles que tenham bem exercido o seu mandato e deitando fora aqueles que tenham sido mal avaliados. Paralelamente, eles utilizam o seu voto com uma visão prospectiva, escolhendo aqueles que, segundo seu julgamento, serão os melhores representantes no próximo mandato, considerando especialmente as políticas que estes se propõem a implementar.

Aliás, James D. Fearon ${ }^{143}$, apoiado em observações empíricas sobre a opinião pública e as eleiçóes nos Estados Unidos da América, entende que os eleitores provavelmente pensam mais nas eleiçóes como oportunidades para selecionar bons representantes para o futuro mandato do que como ocasião para responsabilizar os representantes do mandato vigente.

138 PRZEWORSKI, Adam; STOKES, Susan C.; MANIN, Bernard (Org.). Elections and representation. In: Democracy, accountability, and representation. Cambridge: Cambridge University Press, 1999. p. 40 (tradução nossa).

139 PRZEWORSKI, Adam; STOKES, Susan C.; MANIN, Bernard (Org.). Elections and representation. In: Democracy, accountability, and representation. Cambridge: Cambridge University Press, 1999. p. 44 (tradução nossa).

140 MARAVALL, José María. Accountability and manipulation. In: PRZEWORSKI, Adam; STOKES, Susan C.; MANIN, Bernard (Org.). Democracy, accountability, and representation. Cambridge: Cambridge University Press, 1999. p. 157 (tradução nossa).

141 DUNN, Delmer D. Mixing elected and nonelected officials in democratic policy making: fundamentals of accountability and responsibility. In: PRZEWORSKI, Adam; STOKES, Susan C.; MANIN, Bernard (Org.). Democracy, accountability, and representation. Cambridge: Cambridge University Press, 1999. p. 299.

142 PRZEWORSKI, Adam; STOKES, Susan C.; MANIN, Bernard (Org.). Elections and representation. In: Democracy, accountability, and representation. Cambridge: Cambridge University Press, 1999. p. $29 ; 44-45$.

143 FEARON, James D. Electoral accountability and the control of politicians: selecting good types versus sanctioning poor performance. In: PRZEWORSKI, Adam; STOKES, Susan C.; MANIN, Bernard (Org.). Democracy, accountability, and representation. Cambridge: Cambridge University Press, 1999. p. 56-57. 
Tendo em vista essa realidade, e considerando também que as eleições ocorrem apenas de tempos em tempos, Guillermo O’Donnell ${ }^{144}$ constatou a limitada eficácia da accountability vertical. Luís Felipe Miguel arrola "[...] a complexidade das questóes públicas, o fraco incentivo à qualificação política e o controle sobre a agenda"145 como motivos para a não efetivação da accountability vertical.

Outrossim, Larry Diamond, Marc F. Plattner e Andreas Schedler defendem que “[...] as eleições - embora competitivas, livres e justas - são por si mesmas fracas demais para garantir um governo 'decente'. Elas são uma condição necessária, mas não suficiente, para manter o poder do Estado sob controle"146. Por sua vez, Jeremy Waldron ${ }^{147}$, embora reconheça nas eleições o principal meio de responsabilizar os representantes, entende que sua conexão com a accountability é muito complicada, quando se considera a multiplicidade de aspectos envolvidos na política moderna.

Outra dificuldade, trazida à baila por Adam Przeworski, Susan C. Stokes e Bernard Manin, é que, “[...] se os cidadãos não dispõem de informações suficientes para avaliar os governos em exercício, a ameaça de não serem reeleitos é insuficiente para

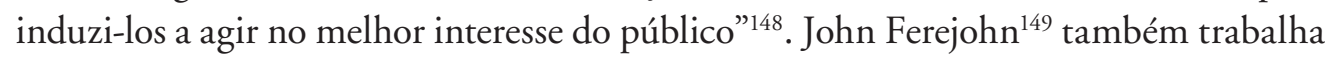
a vantagem informacional dos representantes ante os eleitores como limitação à accountability vertical. Somada à assimetria informacional, José María Maravall ${ }^{150}$ afirma que os cidadãos devem se preocupar com a veracidade das informações - ou desinformação - que lhes são transmitidas pelos meios de comunicação, mesmo aqueles que são independentes do governo, na medida em que estes podem ser dominados por interesses que não necessariamente coincidem com o interesse público.

144 O’DONNELL, Guillermo. Accountability horizontal e novas poliarquias. Lua Nova, São Paulo, n. 44, p. 27-54, 1998. p. 28-30.

145 MIGUEL, Luís Felipe. Impasses da accountability: dilemas e alternativas da representação política. Revista de Sociologia e Política, Curitiba, n. 25, p. 25-38, nov. 2005. p. 27.

146 SCHEDLER, Andreas; DIAMOND, Larry; PLATTNER, Marc F. Introduction. In: The self-restraining state: power and accountability in new democracies. Boulder: Lynne Rienner Publishers, 1999. p. 2 (tradução nossa).

147 WALDRON, Jeremy. Accountability: fundamental to democracy. School of Law, New York University. New York: New York School of Law, 2014. (Public Law \& Legal Theory Reserch Paper Series; Working Paper n. 14-13, apr. 2014). p. 14-15 (tradução nossa).

148 PRZEWORSKI, Adam; STOKES, Susan C.; MANIN, Bernard (Org.). Elections and representation. In: Democracy, accountability, and representation. Cambridge: Cambridge University Press, 1999. p. 30 (tradução nossa).

149 FEREJOHN, John. Accountability and authority: toward a theory of political accountability. In: PRZEWORSKI, Adam; STOKES, Susan C.; MANIN, Bernard (Org.). Democracy, accountability, and representation. Cambridge: Cambridge University Press, 1999. p. 132.

150 MARAVALL, José María. Accountability and manipulation. In: PRZEWORSKI, Adam; STOKES, Susan C.; MANIN, Bernard (Org.). Democracy, accountability, and representation. Cambridge: Cambridge University Press, 1999. p. 163-164. 


\section{•- Contas dos governantes}

Ante o exposto, com Adam Przeworski, Susan C. Stokes e Bernard Manin, conclui-se que "[...] o fato de que os governos devem prestar contas nas urnas é insuficiente para induzir a representação" e assegurar "[...] que os governos farão tudo o que puderem para maximizar o bem-estar dos cidadãos"151. Como consequência, segundo informam Andreas Schedler, Larry Diamond e Marc F. Plattner ${ }^{152}$, cresce a consciência a respeito da necessidade de que os governos, nas democracias representativas, além da responsabilidade perante os cidadãos - por meio das eleições -, devem prestar contas a outros órgãos públicos.

Portanto, ante o apresentado nesta subseção, percebe-se que por meio da dimensão vertical da accountability, incluindo tanto seus aspectos eleitoral e social, a sociedade tenta incutir nos seus representantes a necessidade de fazerem tudo o que estiver ao seu alcance para maximizar o bem-estar dos cidadãos, sob pena de retirar-lhes o apoio nas eleiçóes seguintes. Contudo, mostrando-se a accountability vertical insuficientemente eficaz nesse propósito, emerge a necessidade de desenvolvimento da dimensão horizontal da accountability, apresentada na próxima subseção deste trabalho, como essencial à efetiva responsabilização dos governantes.

\subsubsection{Accountability horizontal}

Ana Carolina Yoshida Hirano de Andrade Mota ${ }^{153}$, ao reconhecer a insuficiência dos mecanismos de accountability vertical para que se tenha uma "boa democracia", defende que os agentes governamentais sejam supervisionados por outros entes públicos. Essa é a solução proposta, também, por Adam Przeworski, Susan C. Stokes e Bernard Manin ${ }^{154}$, que indicam as agências de accountability como instituiçóes que guarneçam os cidadãos de informações independentes sobre o governo - uma das sete exigências da poliarquia de Robert Alan Dahl, conforme apresentado no início deste capítulo 1 (p. 39).

Observe-se que a prestação de contas dos representantes, incluindo os governantes, perante outros órgãos estatais, que são, então, posicionados no polo ativo da rela-

151 PRZEWORSKI, Adam; STOKES, Susan C.; MANIN, Bernard (Org.). Elections and representation. In: Democracy, accountability, and representation. Cambridge: Cambridge University Press, 1999. p. 17; 50 (tradução nossa).

152 SCHEDLER, Andreas; DIAMOND, Larry; PLATTNER, Marc F. Introduction. In: The self-restraining state: power and accountability in new democracies. Boulder: Lynne Rienner Publishers, 1999. p. 1.

153 MOTA, Ana Carolina Yoshida Hirano de Andrade. Accountability no Brasil: os cidadãos e seus meios institucionais de controle dos representantes. 2006. 243 f. Tese (Doutorado em Ciência Política) - Departamento de Ciência Política, Faculdade de Filosofia, Letras e Ciências Humanas, Universidade de São Paulo, São Paulo, 2006. f. 1.

154 PRZEWORSKI, Adam; STOKES, Susan C.; MANIN, Bernard (Org.). Elections and representation. In: Democracy, accountability, and representation. Cambridge: Cambridge University Press, 1999. p. 50 (tradução nossa). 
ção de accountability, é expressão do que Guillermo O’Donnell classificou como accountability horizontal, por ele conceituada como

[...] a existência de agências estatais que têm o direito e o poder legal e que estão de fato dispostas e capacitadas para realizar ações, que vão desde a supervisão de rotina a sanções legais ou até o impeachment contra ações ou omissões de outros agentes ou agências do Estado que possam ser qualificadas como delituosas ${ }^{155}$.

Nesse conceito, deve-se destacar, com Charles D. Kenney ${ }^{156}$, alguns aspectos, a saber, (i) os dois polos da relação de accountability horizontal são ocupados por agentes estatais; (ii) a accountability horizontal envolve a supervisão e eventuais sanções, até mesmo impeachment; e (iii) a accountability horizontal limita-se a ações ou omissões qualificadas como ilegais. Como consequência deste último aspecto, Guillermo O'Donnell ${ }^{157}$ entendia que a accountability horizontal atuava, basicamente, em duas situaçôes, quais sejam, na invasão de competência de uma agência estatal por outra e na corrupção.

Este trabalho, porém, não o acompanha quando limita a atuação da accountability horizontal apenas aos casos em que ocorrem transgressões legais. Antes, com a maioria da literatura, como informa Scott Mainwaring ${ }^{158}$, considera-se aqui que a $a c-$ countability horizontal atua também no campo de responsabilização política.

Nessa corrente, Philippe C. Schmitter critica a suposição de Guillermo O’Donnell segundo a qual a accountability horizontal seria desencadeada pela ilegalidade. Segundo ele, "[...] uma das funçôes democráticas apropriadas da accountability horizontal deve ser manter os governantes responsáveis [accountable] pelas consequências políticas, e não apenas legais, de seu comportamento no cargo"159.

Deve-se ter em mente, porém, que sanções legais são inadequadas para punir ações ou omissões políticas. Nesse sentido, Charles D. Kenney adverte que, "Embora seja frequentemente difícil separar os motivos pessoais e políticos dos argumentos sobre

155 O’DONNELL, Guillermo. Accountability horizontal e novas poliarquias. Lua Nova, São Paulo, n. 44, p. 27-54, 1998. p. 40.

156 KENNEY, Charles D. Horizontal accountability: concepts and conflicts. In: MAINWARING, Scott; WELNA, Christoper. Democratic accountability in Latin America. New York: Oxford University Press, 2003. p. 57.

157 O'DONNELL, Guillermo. Horizontal accountability: the legal institutionalization of mistrust. In: MAINWARING, Scott; WELNA, Christoper. Democratic accountability in Latin America. New York: Oxford University Press, 2003. p. 34.

158 MAINWARING, Scott. Introdução: Democratic accountability in Latin America. In: MAINWARING, Scott; WELNA, Christoper. Democratic accountability in Latin America. New York: Oxford University Press, 2003. p. 11-12; 16.

159 SCHMITTER, Philippe C. The limits of horizontal accountability. In: SCHEDLER, Andreas; DIAMOND, Larry; PLATTNER, Marc F. The self-restraining state: power and accountability in new democracies. Boulder: Lynne Rienner Publishers, 1999. p. 60 (tradução nossa). 


\section{•. Contas dos governantes}

a legalidade dos atos e das omissões, a imposição de sanções jurídicas sem prova de ilegalidade seria, por si só, ilegal”160.

Por isso, neste trabalho concorda-se com ele quando afirma que "[...] as sanções políticas e jurídicas são fundamentais para o conceito de accountability horizontal"161. Acrescenta-se, no contexto da accountability horizontal, às ações ou omissóes políticas, responde-se com sanções políticas, enquanto às ações ou omissões legais responde-se com sanções jurídicas.

Quanto ao primeiro aspecto - já se tratou do segundo e do terceiro, acima - do conceito de accountability horizontal apresentado por Guillermo O’Donnell, tem-se que os agentes envolvidos são estatais. Neste ponto, deve-se esclarecer que a accountability, especialmente sua face horizontal, não se confunde com o princípio da separação de poderes ou com o mecanismo dos freios e contrapesos.

Nessa senda, primeiramente, deve ficar claro que o mecanismo dos freios e contrapesos, embora relacionado com o princípio da separação de poderes, não se confunde com ele. Conforme Adam Przeworski, Susan C. Stokes e Bernard Manin, pela separação de poderes, exige-se "[...] que as três funções tradicionais do governo sejam confiadas a órgãos distintos”, enquanto pelo mecanismo dos freios e contrapesos “[...] cada ramo participa parcialmente na função exercida, principalmente, por outro [...], de modo que eles possam se controlar mutuamente"162. Por todos, Ana Carolina Yoshida Hirano de Andrade Mota ensina que

Identificamos então as características do controle efetuado pelo mecanismo de checks and balances a partir do resgate do debate travado entre federalistas e anti-federalistas. Com a recuperação das idéias de ambos os lados, foi possível concluir que são mecanismos de controle intra-institucional, com o objetivo de limitar a força das instituições da estrutura de poder em relação a elas próprias, e não com o fim de proteger interesses advindos da população. Neste sentido, os sujeitos ativos e passivos do exercício dos checks and balances são os próprios Poderes enquanto instituições também portadoras de poder. Daí se concluir que não são instrumentos suficientes e eficazes para controlar a burocracia, pelo simples fato de não terem este objetivo.

A divisão de poderes, embora alegadamente funcional, ainda era representativa de orientaçôes de diferentes grupos sociais que preponderavam em determinados se-

160 KENNEY, Charles D. Horizontal accountability: concepts and conflicts. In: MAINWARING, Scott; WELNA, Christoper. Democratic accountability in Latin America. New York: Oxford University Press, 2003. p. 66-67 (tradução nossa).

161 KENNEY, Charles D. Horizontal accountability: concepts and conflicts. In: MAINWARING, Scott; WELNA, Christoper. Democratic accountability in LatinAmerica. New York: Oxford University Press, 2003. p. 60-61 (tradução nossa).

162 PRZEWORSKI, Adam; STOKES, Susan C.; MANIN, Bernard (Org.). Introduction. In: Democracy, accountability, and representation. Cambridge: Cambridge University Press, 1999. p. 17 (tradução nossa). 
tores. Portanto, constituíam mecanismo de controle entre elites diferentes, e não a favor de uma cidadania ativa, mesmo porque o conceito de cidadania ainda não era aplicado em seu patamar máximo. Ao fim desta análise pudemos evidenciar que o controle efetivado via checks and balances não tem como fim preponderante evitar descaminhos da gestão da coisa pública, mas sim, evitar a usurpação de poderes entre os próprios poderes ${ }^{163}$.

Isto considerado, que o mecanismo de freios e contrapesos não tem o objetivo precípuo de controlar a burocracia, de proteger os interesses da população ou evitar descaminhos da coisa pública, também não deve ser confundido, como argumentam Charles D. Kenney ${ }^{164}$ e Scott Mainwaring ${ }^{165}$, com o conceito de accountability horizontal. Aliás, Ana Carolina Yoshida Hirano de Andrade Mota explica que, embora tanto os federalistas quanto Montesquieu tenham se referido expressamente aos checks and balances e à accountability, "[...] a demanda mais substancial por accountability entra em cena somente a partir da adoção do sufrágio universal nos governos modernos e contemporâneos"166. Segundo ela,

[...] se os checks and balances são mecanismos ínsitos à engrenagem estatal, com o fim de controlar o poder intra-elites institucionais, a accountability contemporânea é um mecanismo institucional colocado à disposição de um cidadão qualquer, integrante ou não da engrenagem estatal, à serviço de seus interesses e dos interesses de sua comunidade ${ }^{167}$.

Dirimidas quaisquer dúvidas sobre a relação entre o princípio da separação de poderes, o mecanismo dos freios e contrapesos e a accountability horizontal, deve-se ter em mente que - segundo a abordagem proposta neste trabalho ${ }^{168}$, que segue a linha de

163 MOTA, Ana Carolina Yoshida Hirano de Andrade. Accountability no Brasil: os cidadãos e seus meios institucionais de controle dos representantes. 2006. 243 f. Tese (Doutorado em Ciência Política) - Departamento de Ciência Política, Faculdade de Filosofia, Letras e Ciências Humanas, Universidade de São Paulo, São Paulo, 2006. f. 233-234.

164 KENNEY, Charles D. Horizontal accountability: concepts and conflicts. In: MAINWARING, Scott; WELNA, Christoper. Democratic accountability in Latin America. New York: Oxford University Press, 2003. p. 60.

165 MAINWARING, Scott. Introdução: Democratic accountability in Latin America. In: MAINWARING, Scott; WELNA, Christoper. Democratic accountability in Latin America. New York: Oxford University Press, 2003. p. 16.

166 MOTA, Ana Carolina Yoshida Hirano de Andrade. Accountability no Brasil: os cidadãos e seus meios institucionais de controle dos representantes. 2006. 243 f. Tese (Doutorado em Ciência Política) - Departamento de Ciência Política, Faculdade de Filosofia, Letras e Ciências Humanas, Universidade de São Paulo, São Paulo, 2006. f. 9.

167 MOTA, Ana Carolina Yoshida Hirano de Andrade. Accountability no Brasil: os cidadãos e seus meios institucionais de controle dos representantes. 2006. 243 f. Tese (Doutorado em Ciência Política) - Departamento de Ciência Política, Faculdade de Filosofia, Letras e Ciências Humanas, Universidade de São Paulo, São Paulo, 2006. f. 235.

168 Abordagem diferente é adotada por Mark Bovens, cujo conceito de accountability pública abrange a ideia de accountability organizacional, na qual os superiores hierárquicos funcionam como agentes de accoun- 


\section{.- Contas dos governantes}

Charles D. Kenney ${ }^{169}$ e Andreas Schedler ${ }^{170}$ - esta não envolve as relaçôes internas de determinada agência governamental, mas trata-se da accountability entre agências.

Para Charles D. Kenney ${ }^{171}$, o sujeito da accountability é o agente perante o qual as contas são prestadas e o objeto da accountability é o agente que presta as contas. Neste trabalho, porém, entende-se que a relação de accountability fica melhor caracterizada tomando o agente que presta as contas e aquele perante quem elas são prestadas como seus sujeitos, respectivamente, passivo e ativo - este o agente de accountability -, enquanto o objeto da accountability seria composto pelas ações e omissões do sujeito passivo.

Tendo em vista o conceito de accountability apresentado anteriormente neste capítulo, deve-se destacar que o sujeito ativo da accountability horizontal nem sempre é o principal da relação de agência relacionada. Como arrolam Andreas Schedler, Larry Diamond e Marc F. Plattner, exercem, quando cabível, a função de agente de accountability: “[...] comissões eleitorais, tribunais eleitorais, órgãos de auditoria, órgãos anticorrupção, ombudsmen, tribunais administrativos, tribunais constitucionais, comissôes de direitos humanos e bancos centrais"172. Erika Moreno, Brian F. Crisp e Mathew Søberg Shugart ${ }^{173}$ incluem o Judiciário, os promotores públicos, a defensoria pública e os controladores-gerais nessa relação. Ana Carolina Yoshida Hirano de Andrade Mota ${ }^{174}$, além desses, lembra especificamente dos tribunais de contas e das comissóes parlamentares de inquérito.

tability em relação aos seus subordinados na estrutura administrativa, cf. BOVENS, Mark. Public accountability. In: FERLIE, Ewan; LYNN, Laurence E.; POLLITT, Christopher. The Oxford Handbook of Public Management. New York: Oxford University Press, 2005. Disponível em: http:// dspace.library.uu.nl/handle/1874/15015. Acesso em: 23 jan. 2017. p. 186-188.

169 KENNEY, Charles D. Horizontal accountability: concepts and conflicts. In: MAINWARING, Scott; WELNA, Christoper. Democratic accountability in Latin America. New York: Oxford University Press, 2003. p. 62.

170 SCHEDLER, Andreas. Conceptualizing accountability. In: SCHEDLER, Andreas; DIAMOND, Larry; PLATTNER, Marc F. The self-restraining state: power and accountability in new democracies. Boulder: Lynne Rienner Publishers, 1999. p. 24

171 KENNEY, Charles D. Horizontal accountability: concepts and conflicts. In: MAINWARING, Scott; WELNA, Christoper. Democratic accountability in Latin America. New York: Oxford University Press, 2003. p. 60-61.

172 SCHEDLER, Andreas; DIAMOND, Larry; PLATTNER, Marc F. The self-restraining state: power and accountability in new democracies. Boulder: Lynne Rienner Publishers, 1999. p. 3 (tradução nossa).

173 MORENO, Erika; CRISP, Brian F.; SHUGART, Mathew Søberg. The accountability deficit in Latin America. In: MAINWARING, Scott; WELNA, Christoper. Democratic accountability in Latin America. New York: Oxford University Press, 2003. p. 81; 91.

174 MOTA, Ana Carolina Yoshida Hirano de Andrade. Accountability no Brasil: os cidadãos e seus meios institucionais de controle dos representantes. 2006. 243 f. Tese (Doutorado em Ciência Política) - Departamento de Ciência Política, Faculdade de Filosofia, Letras e Ciências Humanas, Universidade de São Paulo, São Paulo, 2006. f. 236-237. 
Como observava Guillermo O’Donnell ${ }^{175}$, as denominadas agências de accountability foram concebidas não para manter os equilíbrios globais de poder, mas especificamente para suprir a demanda de accountability horizontal. Tal demanda, diga-se, é dos cidadãos, isoladamente ou em conjunto, e visa seus interesses ou os interesses da comunidade da qual fazem parte. Essa origem, segundo ele, trouxe-lhes algumas vantagens, como (i) a continuidade de suas atividades; (ii) a proatividade; e (iii) a utilização de critérios técnico-profissionais, em detrimento de critérios políticos.

Scott Mainwaring ${ }^{176}$ e Richard Mulgan ${ }^{177}$ acrescentam o parlamento à lista de agentes de accountability horizontal. Porém, apesar de efetivamente funcionarem como agentes de accountability - inclusive em relação à gestão financeira e orçamentária da Administração Pública, como se apresenta na seção 2.4 (p. 97) deste trabalho -, os parlamentos não foram desenvolvidos especificamente para exercerem tal função, motivo pelo qual não carregam as vantagens elencadas por Guillermo O’Donnell, enumeradas no parágrafo anterior, especialmente a da preferência por critérios técnico-profissionais, ante os critérios políticos.

Guillermo O’Donnell ${ }^{178}$ e Charles D. Kenney ${ }^{179}$ destacam que muitos dos agentes de accountability horizontal, para formar um sistema de accountability efetivo, precisam trabalhar em rede ${ }^{180}$. Segundo o primeiro, especialmente quando se trata de responsabilizar as mais altas autoridades governamentais, a eficácia final das agências de accountability normalmente depende dos tribunais judiciários ou dos legisladores - como no caso de impeachment -, "Caso contrário, as investigações de órgãos de

175 O'DONNELL, Guillermo. Horizontal accountability: the legal institutionalization of mistrust. In: MAINWARING, Scott; WELNA, Christoper. Democratic accountability in Latin America. New York: Oxford University Press, 2003. p. 45-46.

176 MAINWARING, Scott. Introdução: Democratic accountability in Latin America. In: MAINWARING, Scott; WELNA, Christoper. Democratic accountability in Latin America. New York: Oxford University Press, 2003. p. 16.

177 MULGAN, Richard. The processes of public accountability. Australian Journal of Public Administration, v. 56, n. 1, p. 25-36, Mar. 1997. p. 29.

178 O'DONNELL, Guillermo. Horizontal accountability in new democracies. In: SCHEDLER, Andreas; DIAMOND, Larry; PLATTNER, Marc F. The self-restraining state: power and accountability in new democracies. Boulder: Lynne Rienner Publishers, 1999. p. 39.

179 KENNEY, Charles D. Horizontal accountability: concepts and conflicts. In: MAINWARING, Scott; WELNA, Christoper. Democratic accountability in Latin America. New York: Oxford University Press, 2003. p. 65.

180 A respeito da necessidade de atuaçáo coordenada dos agentes de accountability horizontal, para que a sanção seja aplicada de forma adequada, cf. ROBL FILHO, Ilton Norberto; GARCIA JÚNIOR, Raul Greenhalgh. Corrupção: uma análise a partir da economia institucional e da accountability horizontal em busca da efetividade do controle da administração pública. Constituição, Economia e Desenvolvimento: Revista da Academia Brasileira de Direito Constitucional, Curitiba, v. 10, n. 19, p. 478497, jul./dez. 2018. DOI: 10.24068/2177.8256.2018.10.19;478.497. 


\section{•- Contas dos governantes}

auditorias, fiscalias e similares podem alimentar uma opinião pública irritada, mas não alcançam uma resolução legalmente apropriada" 181 .

Como se destaca em pontos anteriores deste capítulo, a existência de fontes de informação alternativas ao governo é uma das instituições essenciais à caracterização das poliarquias de Robert Alan Dahl. Nesse sentido, Delmer D. Dunn ${ }^{182}$ defende que a liberdade de informação é essencial à democracia representativa moderna.

Assim, como advertem Adam Przeworski, Susan C. Stokes e Bernard Manin, "Nossa informação não deve depender do que os governos querem que saibamos. [...] precisamos de comissóes eleitorais independentes, de escritórios de contabilidade independentes, de agências estatísticas independentes"183. Como explica Argelina Cheibub Figueiredo, "Uma vez que os mecanismos de accountability horizontal obrigam o executivo a justificar e defender suas ações perante outros ramos do governo, eles também servem para informar os cidadãos"184.

Guillermo O’Donnell reconheceu que, embora as agências de accountability não sejam, em geral, projetadas com essa finalidade, a accountability horizontal é "[...] um importante gerador de informações que se tornam publicamente disponíveis" ${ }^{85}$. Erika Moreno, Brian F. Crisp e Mathew Søberg Shugart também destacam o papel das agências de accountability horizontal como "alarme de incêndio da accountability vertical"186, na medida em que os eleitores podem usar a informação por elas geradas para responsabilizar os representantes nas eleições seguintes.

Neste ponto, ao observar a relação da accountability pública com as tradições democrática, republicana e liberal, percebe-se que, como ensina Guillermo O’Donnell ${ }^{187}$, quando se pode dizer que há accountability vertical em determinado país, pode-se

181 O'DONNELL, Guillermo. Horizontal accountability: the legal institutionalization of mistrust. In: MAINWARING, Scott; WELNA, Christoper. Democratic accountability in Latin America. New York: Oxford University Press, 2003. p. 47 (tradução nossa).

182 DUNN, Delmer D. Mixing elected and nonelected officials in democratic policy making: fundamentals of accountability and responsibility. In: PRZEWORSKI, Adam; STOKES, Susan C.; MANIN, Bernard (Org.). Democracy, accountability, and representation. Cambridge: Cambridge University Press, 1999. p. 338-339.

183 PRZEWORSKI, Adam; STOKES, Susan C.; MANIN, Bernard (Org.). Introduction. In: Democracy, accountability, and representation. Cambridge: Cambridge University Press, 1999. p. 24 (tradução nossa).

184 FIGUEIREDO, Argelina Cheibub. The role of Congress as an agency of horizontal accountability: lessons of Brazilian experience. In: MAINWARING, Scott; WELNA, Christoper. Democratic accountability in Latin America. New York: Oxford University Press, 2003. p. 191 (tradução nossa).

185 O'DONNELL, Guillermo. Horizontal accountability: the legal institutionalization of mistrust. In: MAINWARING, Scott; WELNA, Christoper. Democratic accountability in Latin America. New York: Oxford University Press, 2003. p. 50-51 (tradução nossa).

186 MORENO, Erika; CRISP, Brian F.; SHUGART, Mathew Søberg. The accountability deficit in Latin America. In: MAINWARING, Scott; WELNA, Christoper. Democratic accountability in Latin America. New York: Oxford University Press, 2003. p. $96-97$ (tradução nossa).

187 O’DONNELL, Guillermo. Accountability horizontal e novas poliarquias. Lua Nova, São Paulo, n. 44, p. 27-54, 1998. p. 30. 
afirmar que ele é democrático. Contudo, é necessária a existência concomitante da accountability horizontal para confirmar a robustez dos componentes liberal e republicano de sua democracia representativa.

Aliás, pela conclusão de Charles D. Kenney ${ }^{188}$, na tradição especificamente democrática, cujo axioma é a regra majoritária, enquanto a accountability vertical é fundamental, com a essencial responsabilização dos representantes pelos cidadãos, a accountability horizontal não tem papel central, tendo a principal função de evitar a sabotagem da accountability vertical. Mas, segundo Guillermo O'Donnell, as expectativas democráticas "[...] têm como consequência a demanda por um alto grau de transparência na tomada de decisão política, o que tem ao menos potencialmente uma implicação anticorrupção"189.

Por outro lado, nas tradições republicana e liberal, como ensina Charles D. Kenney ${ }^{190}$, enquanto a accountability vertical não é essencial, a accountability horizontal é fundamental. Assim, no republicanismo - cujo princípio regente é a regra do interesse público -, a accountability horizontal é fundamental para controlar o poder e desencorajar a corrupção, ao passo que no liberalismo ela é fundamental para assegurar que o Estado cumpra sua função principal, que é proteger determinados direitos vistos como inalienáveis.

Por conseguinte, não somente no plano geral, mas também especificamente em se tratando de accountability pública, as democracias representativas contemporâneas resultam da simbiose do democratismo, do republicanismo e do liberalismo.

Por todo o exposto neste capítulo, nas democracias atuais, os governantes têm a obrigação de prestar contas - incluindo tanto a prestação de informações como a apresentação de argumentos que justifiquem a sua atuação - de suas ações ou omissões não somente aos eleitores e à sociedade de maneira geral, no foro da accountability vertical, como perante as agências estatais a que o sistema jurídico tenha formalmente capacitado para responsabilizar-lhes, na expressão da accountability horizontal.

Tal sujeição dos governantes à accountability deve ocorrer em todos os campos de sua atuação, de forma que os conceitos e fundamentos expostos neste capítulo, têm ampla aplicação. Logo, aplicam-se, inclusive, à gestão financeira e orçamentária da Administração Pública, cujo sistema de accountability, instituído pela CRFB/1988, é objeto do próximo capítulo deste trabalho.

188 KENNEY, Charles D. Horizontal accountability: concepts and conflicts. In: MAINWARING, Scott; WELNA, Christoper. Democratic accountability in Latin America. New York: Oxford University Press, 2003. p. 69.

189 O’DONNELL, Guillermo. Accountability horizontal e novas poliarquias. Lua Nova, São Paulo, n. 44, p. 27-54, 1998. p. 46-47.

190 KENNEY, Charles D. Horizontal accountability: concepts and conflicts. In: MAINWARING, Scott; WELNA, Christoper. Democratic accountability in Latin America. New York: Oxford University Press, 2003. p. 69. 